\title{
Awareness and Attitude towards Organ Donation: A Community Survey in Urban and Rural Populations, from Sangli District of Maharashtra
}

\author{
Dhamdhere Samruddhi Sunil', Waghachavare Vivek Baliram²,*, Kadam Prashant Raghunath², Dhumale Girish \\ Bhimrao², Quraishi Sanjay Raguel $^{2}$
}

Dhamdhere Samruddhi Sunil', Waghachavare Vivek Baliram ${ }^{2, *}$, Kadam Prashant Raghunath ${ }^{2}$, Dhumale Girish Bhimrao², Quraishi Sanjay Raguel ${ }^{2}$

'Department of Bharati Vidyapeeth University Medical College and Hospital, Sangli, Maharashtra, INDIA. ${ }^{2}$ Department of Community Medicine, Bharati Vidyapeeth (Deemed to be University) Medical College and Hospital, Sangli, Maharashtra, INDIA.

\section{Correspondence}

Dr. Vivek Baliram Waghachavare,

Department of Bharati Vidyapeeth University Medical College and Hospital, To Market Yard, Near Hotel Shivechha, Sangli-Miraj Road, Sangli-416416, Maharashtra, INDIA.

Phone no: +91 8830483862

Email: vivek416416@gmail.com

History

- Submission Date: 19-06-2019

- Revised Date: 04-10-2019

- Accepted Date: 31-10-2019

DOI : 10.5530/ijmedph.2019.3.21

Article Available online

http://www.ijmedph.org/v9/i3

\section{Copyright}

(C) 2019 Phcog.Net. This is an openaccess article distributed under the terms of the Creative Commons Attribution 4.0 International license.

\begin{abstract}
Introduction: Timely organ transplantation can save many lives as well as better the quality of life for many more. However there is scarcity of organ donation in India. Hence the current research was planned to study, awareness and attitude of the people towards organ donation. Methods: A cross-sectional study was conducted among the rural and urban residents in Sangli district (Maharashtra, India). Informed consent was taken. Self-administered questionnaire was used for data collection. Study period was July to September 2018. The sampling technique used was convenience sampling. Descriptive statistics, chi-square test and Binary logistic regression were used for statistical analysis. Results: Four hundred and ten participants were included in final analysis. Good knowledge regarding organ donation was observed in 130 (31.7\%) participants, while 261 (63.7\%) had good attitude. On applying binary logistic regression; residence and education were best predictors of knowledge regarding organ donation. While knowledge was the best predictor for attitude towards organ donation. Conclusion: Knowledge can bring about change in attitude towards organ donation, hence concentrated efforts should be made to raise the awareness.

Key words: Organ Transplantation, Directed Organ Donations, Attitude, Awareness, India.
\end{abstract}

\section{INTRODUCTION}

"An ounce of prevention is worth a pound of cure", a phrase suitably highlights the importance of prevention of a crisis rather than its mitigation. Currently, we understand the importance of prevention so lot of efforts are made globally for disease prevention and health promotion. ${ }^{1}$ However, the disease occurrences are inevitable so the availability and accessibility to effective management is important. Many end stage diseases of kidneys, liver, lungs and heart etc. can be managed better with organ transplantation. In some diseases it is the only option to ensure survival of the patients. ${ }^{2}$ Similarly organ transplantation has been proven as an important modality in non-fatal conditions like uterine infertility. ${ }^{3}$ Hence to facilitate and regulate the organ transplantations in India, Govt. of India had passed, Transplantation of Human Organs Act (THOA) 1994 act which was later modified by Transplantation of Human Organs (Amendment) Act 2011. ${ }^{4}$

Global Observatory on Donation and Transplantation (GODT) was established in collaboration between the World Health Organization and the Spanish Transplant Organization, Organización Nacional de Trasplantes (ONT) to maintain the data on organ donation and transplantation. It estimates that in
2016, globally 135860 solid organ were transplanted which was less than $10 \%$ of global needs. The deceased organ donors were only $34854 .^{5}$ The situation in India is even more grim with only 411 (or 0.34 per million population) organ donations in $2014 .{ }^{6}$ While estimated 500000 people die suffering with end stage organ failure and 150000 renal patients had to be managed on repeated dialysis. This mortality and morbidity can be reduced dramatically by organ donation.

Various Indian studies had observed the socio-cultural factors like religion, lack of awareness, ineffective and incomplete communication, perception issues and lack of supporting infrastructure as major road blocks for organ donation in India. ${ }^{8-10}$ Sarveswaran G et al. had observed that $72 \%$ participants from urban Puducherry had inadequate knowledge regarding organ donation. ${ }^{11}$ Similar state of poor awareness was observed in studies conducted in Maharashtra. ${ }^{12,13}$

However, the studies that have made efforts to understand the issue in India are very few and these are largely limited to urban area. Any comparative studies for better understanding of urban-rural difference are ever rarer. The present study was undertaken in order to assess the awareness and attitude of people 
regarding organ donation, in rural and urban area from the Sangli district of Western Maharashtra, India.

\section{METHODS}

A cross-sectional study was conducted in an urban and rural area of the Sangli district of Western Maharashtra. The institutional ethical committee approved the study (IEC letter no. BVDUMC\&H/S/IEC/289/18; Dated: 09/01/2018). A previous study from India had observed awareness of organ donation at $88 \% ;{ }^{14}$ hence the calculated sample size for this study was 170 each for rural and urban area. The sampling technique applied was convenience sampling. A village under catchment area of Rural Health Training center of a medical college was selected as rural sample, while catchment area of Urban Health Training centre was selected as urban sample. The study was conducted from July to September 2018. All willing literate adults who were able to understand Marathi, were included in the study. Informed consent in written was obtained separately from each study subject. Care was taken to establish confidentiality and comfort, while completion of the questionnaire. One of the researcher was always present during the completion of questionnaire for clearance of any doubts; without interrupting and involving in answering process. The questionnaire were collected in a sealed drop box, which were opened at the completion of data collection process.

The study tool was pre-designed, self-administered questionnaire in Marathi. It was designed, based on published literature with the help of experts in the field and language experts. It had three sections. The first section had questions regarding socio-demographic variables like age, gender, etc. The second section was knowledge regarding organ donation subscale. It was four itemed scale with multiple choice, multiple responses type of questions. The possible score to be obtained ranged from 0 to 14. The second subscale was attitude towards organ donation subscale. It was again four itemed scale with multiple choice, multiple responses type of questions. The possible score to be obtained ranged from 0 to 4. The questionnaire was examined and pilot tested. The data from the pilot study was not used in final analysis. The score of $\geq 50 \%$ was to be considered as good and $<50 \%$ as poor for each subscale. The subscales had good reliability (Cronbach's a for knowledge and attitude subscales was 0.63 and 0.69 respectively).

Percentages, descriptive statistics, chi-square test and Binary logistic regression were used for statistical analysis. Analysis was done using Microsoft Excel 2003 and IBM SPSS Statistics-22 software.

\section{RESULTS}

Of the 553 people approached for participation, 410 (74.14\%) had duly completed the questionnaire and hence included in the final analysis. The average age of the stduy participants was 41.48 years (s.d. \pm 16.104 , range $18-85$ yrs). Majority of the study participants were females 228 (55.6\%) and belonged to urban area 211 (51.5\%). Number of respondents that belonged to age group of 18-35 yrs, 36-60 yrs and above 60 years was $188(45.9 \%), 170(41.5 \%)$ and $52(12.7 \%)$ respectively. Secondary schooling was the most frequently observed education qualification with 183 (44.6\%) participants. Considering the occupation of participants, majority 127 (31\%) were farmers while $116(28.3 \%)$ were businessmen. Eighty two $(20 \%)$ participants were full time home-makers.

Most of the participants 376 (91.7\%) were married, belonged to joint family $340(82.9 \%)$ and were Hindu by religion 377 (92\%). Thirteen (3.2\%) participants had a differently abled person in the family. Only 3 $(0.7 \%)$ participants had actually signed up for eye donation, while none of them had signed up for organ donation.

Newspapers were the source of information on organ donation for 283 $(68.3 \%)$ participants. Other source of information as reported by study participants were television and internet 165 (40.2\%), radio $89(21.7 \%)$, friends or family 105 (25.6\%) and other sources like health workers, syllabus etc. 40 (9.8\%).

Now considering knowledge regarding organ donation, 280 (68.3\%) participants had poor knowledge while 130 (31.7\%) had good knowledge. The mean knowledge score of the participants was $3.22( \pm 3.08)$, only three participants had achieved score of 9 . The mean attitude score was $2.49( \pm 1.23)$. Knowledge was significantly associated with gender, age, education, residence and occupation. (Table 1)

Of the total participants, 171 (41.71\%) were aware about brain dead deceased person can donate organs. While 51 (12.44\%) participants answered that healthy alive people can donate organs too. Majority of participants 243 (59.27\%) were aware that eyes (cornea) can be donated. Number of participants who were aware that kidney, liver and heart can be donated was 175 (42.68\%), 157 (38.29\%) and 146 (35.61\%) respectively. However very few to none of the participants were aware that skin, bones, tissues, pancreas and lungs can also be donated. On the question of consent for organ donation, 161 (39.27\%) were uninformed, while 161 (39.27\%) were aware that a person can pledge for organ donation during lifetime and 206 (50.24\%) were aware that legal relatives can decide for deceased organ donation.

Majority of the participants $261(63.7 \%)$ had good attitude towards organ donation, while 149 (36.3\%) had poor attitude. Attitude was significantly associated with gender, age, education, residence and occupation. (Table 2)

There was statistically significant association between knowledge and attitude about organ donation (Chi-square $=47.528, \mathrm{df}=1, P$-value $<$ $0.001)$. Out of 130 respondents with good knowledge, 114 (87.7\%) had good attitude too. While out of the 280 respondents with poor knowledge, 147 (52.5\%) had good attitude.

Currently, 201 (49.02\%) were ready to pledge for organ donation. While answering the question regarding motivation if they ever decide to donate organ, $89(21.71 \%)$ participants replied that saving a very close relative / friend could only be prime factor for such decision. Seventy two (17.57\%) believed that organ donation was against their religious / cultural beliefs. While $41(10 \%)$ believed that organ donation affects once journey in afterlife.

On applying binary logistic regression; residence and education were best predictors of knowledge regarding organ donation. While knowledge was the best predictor for attitude towards organ donation. (Table 3)

\section{DISCUSSION}

In the current out of the total people contacted only $74.14 \%$ had ever heard about the concept of organ donation. Tamuli RP et al. conducted such survey in North-East India and observed that $79.17 \%$ participants were aware about organ donation. ${ }^{15}$ While Sarveswaran G et al. observed that almost $90 \%$ of participants from urban Puducherry were aware about it. ${ }^{11}$ Hence observation in the current studies were similar to the observations from North East India, while considerably lesser than the study from Puducherry. The geographical variation may have been responsible for such variation. Similarly South India especially Tamil Nadu leads in India in organ transplant and hence is focused in media. ${ }^{16} \mathrm{How}-$ ever, the samples from all the three studies were limited to few hundreds and these were not extensive surveys hence may not be accurately reflective of situation of the population.

Newspapers, television and radio were the major sources of information regarding organ donation in the current study. While these were also the major source of information as observed by similar studies in India. ${ }^{11,12}$ 


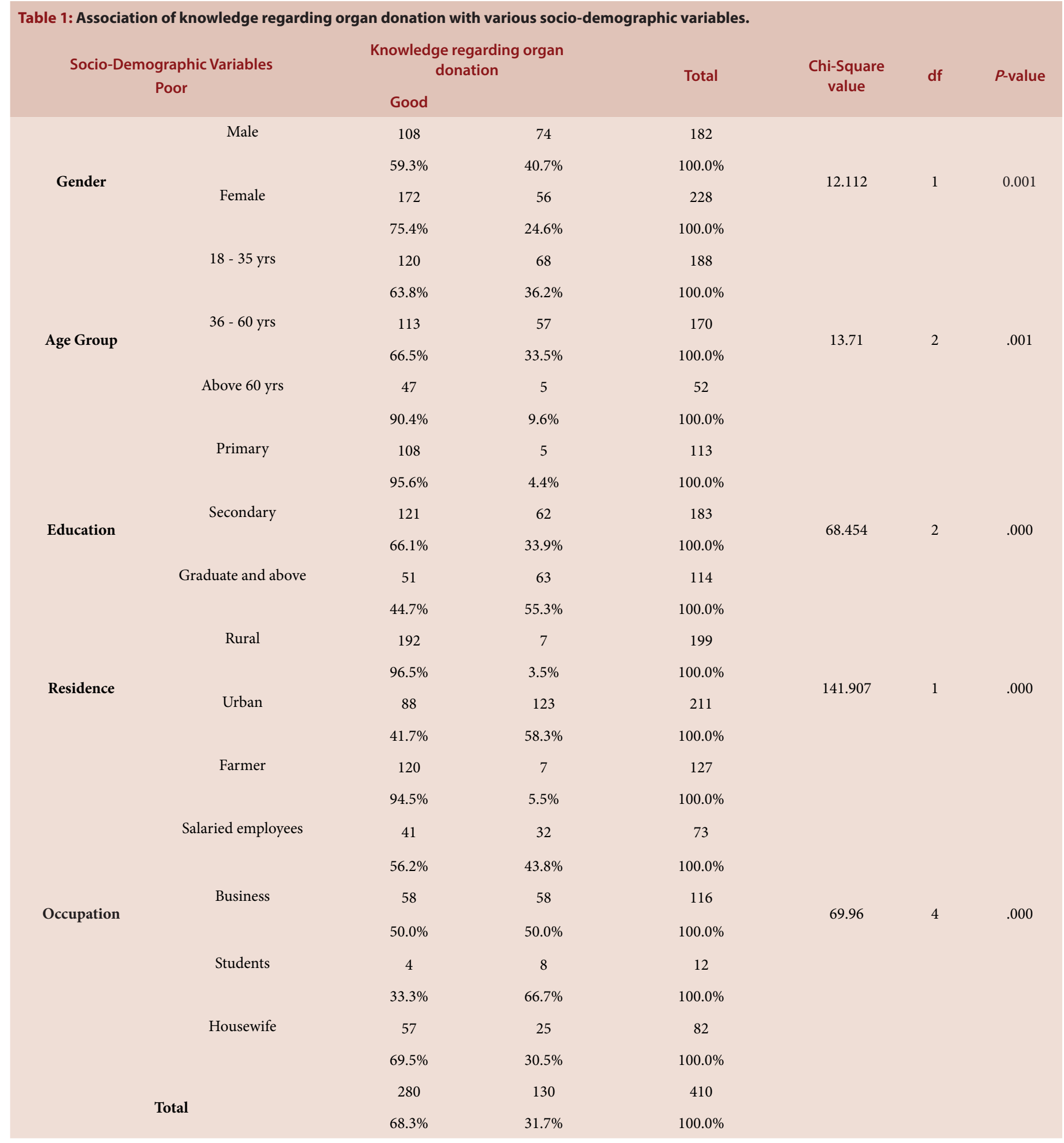

In the current study less than $32 \%$ participants had good knowledge while more than $63 \%$ participants had good attitude towards organ donation. In her study conducted in Bengaluru, Vijaylakshmi et al. observed that $52.8 \%$ of the participants had adequate knowledge and $67 \%$ had a positive attitude towards organ donation. ${ }^{17}$ While Sarveswaran et al. observed in Urban Puducherry that only 28\% participants had adequate knowledge and $58 \%$ had positive attitude toward organ donation. ${ }^{11}$ Hence the current observations were similar to the previous such studies.
In the current study we observed that, people were better aware about deceased organ donation, rather than healthy live organ donation. Similarly, considering the organs that can be donated, most of the people were aware of eye donation, followed by kidneys. Awareness regarding skin, bones, tissues, pancreas and lungs was almost non-existent. Similar observation were made by other such Indian studies, people were generally aware about eye donation followed by kidney donation. ${ }^{11-13}$ The ex- 


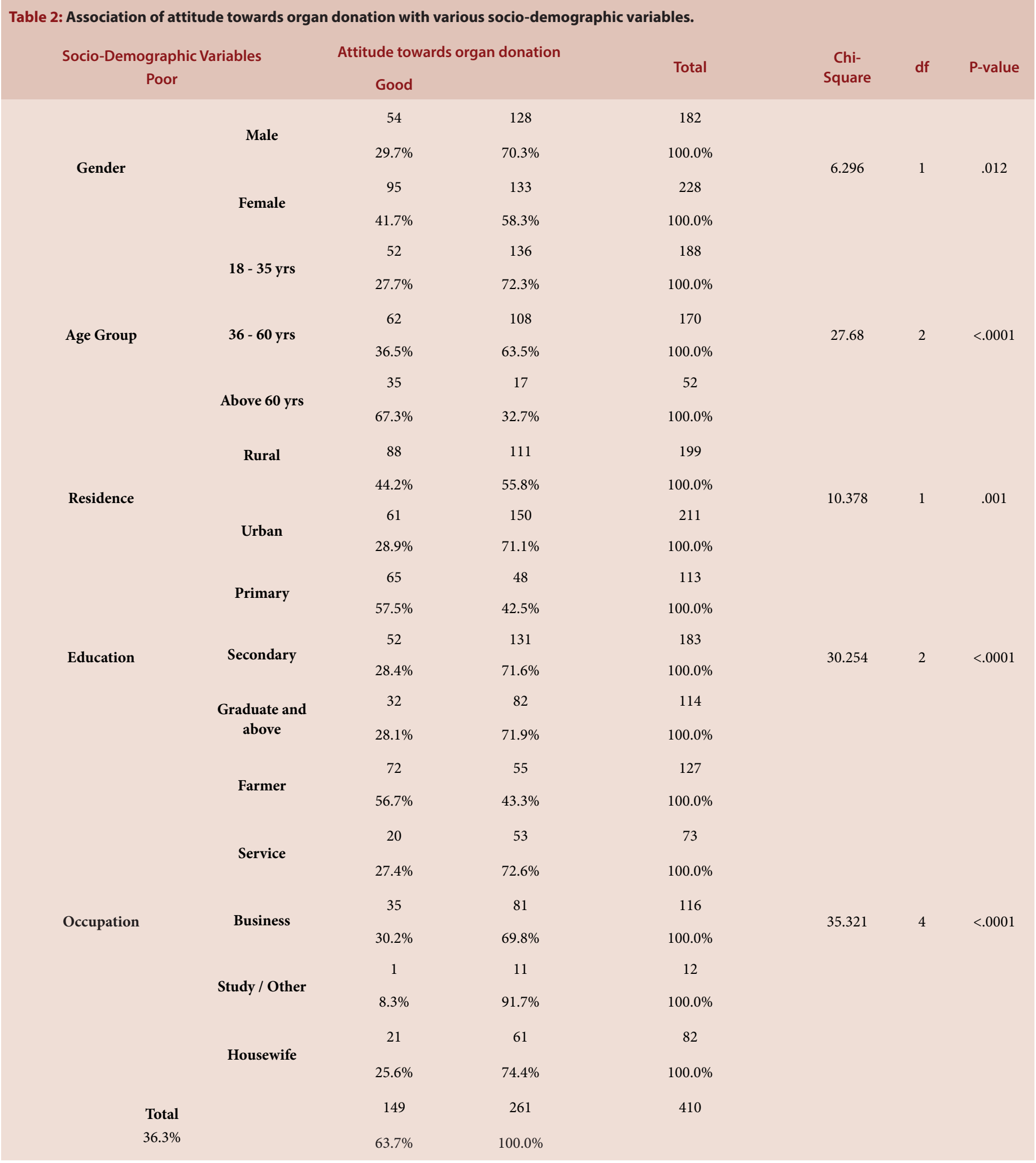

tensive mass media campaigns using celebrities in recent years might be the reason behind such awareness.

Just under $20 \%$ respondents believed organ donation was against religious beliefs, while $10 \%$ believed organ donation can affect afterlife. Saving was friend/ family member was commonly reported motivation for organ donation. In a similar study conducted in rural Pakistan, similar results were observed with nearly $20 \%$ believing that organ donation was against religious beliefs and saving family member was the main motivation. $^{18}$

When considering the information of legal provisions of organ donation, only $50 \%$ participants knew that family of deceased can donate organs. Similar observations were made by Bharambe VK et al. ${ }^{12}$ 


\begin{tabular}{|c|c|c|c|c|c|c|c|}
\hline \multicolumn{8}{|c|}{ Knowledge regarding organ donation } \\
\hline Variables & B & S.E. & Wald & df & Sig. & $\operatorname{Exp}(B)$ & 95\% C.I.for EXP(B) \\
\hline Age & -.031 & .013 & 6.083 & 1 & .014 & .969 & $0.946-0.994$ \\
\hline Gender & -.264 & .337 & .615 & 1 & .433 & .768 & $0.397-1.485$ \\
\hline Residence & 4.487 & .498 & 81.223 & 1 & .000 & 88.862 & $33.490-235.781$ \\
\hline Education & 1.380 & .269 & 26.303 & 1 & .000 & 3.973 & $2.345-6.731$ \\
\hline Occupation & .483 & .140 & 11.923 & 1 & .001 & 1.621 & $1.232-2.132$ \\
\hline Constant & -10.982 & 1.597 & 47.269 & 1 & .000 & .000 & \\
\hline \multicolumn{8}{|c|}{ Attitude towards organ donation } \\
\hline Age & -.022 & .009 & 5.619 & 1 & .018 & .979 & $0.961-0.996$ \\
\hline Gender & -.643 & .252 & 6.537 & 1 & .011 & .526 & $0.321-0.861$ \\
\hline Residence & 0.137 & .294 & 0.215 & 1 & .643 & 1.146 & $0.644-2.041$ \\
\hline Education & -0.002 & .178 & 0.000 & 1 & .990 & 0.998 & $0.704-1.414$ \\
\hline Occupation & .212 & .086 & 6.139 & 1 & .013 & 1.237 & $1.045-1.463$ \\
\hline $\begin{array}{l}\text { Knowledge regarding organ } \\
\text { donation }\end{array}$ & .243 & .052 & 21.590 & 1 & .000 & 1.275 & $1.151-1.412$ \\
\hline Constant & 1.080 & 0.800 & 1.822 & 1 & .177 & 2.945 & \\
\hline
\end{tabular}

$\mathrm{B}=$ coefficient of regression; $\mathrm{SE}=$ standard error of mean; Wald = wald statistic; $\mathrm{d}_{f}=$ degree of freedom; $\mathrm{Sig}=$ significance; $95 \% \mathrm{CI}$ for $\operatorname{EXP}(B)=95 \%$ confidence interval for odds ratio.

\section{CONCLUSION}

Majority of the people have poor knowledge regarding organ donation. Similarly, considerable amount of them have poor attitude regarding the matter. For many of them religious beliefs still play important role in decision making. Similar many people are unaware of the methods to consent/ pledge for organ donation. Most of the people are aware of only few organs that can be transplanted. However it is seen that better knowledge leads to better attitude development. Hence more awareness has to create using behavioural change communication through mass media and personal approach.

\section{Limitations of the study}

Study population is geographically limited and sampling technique was convenience sampling. Similarly the study is cross-sectional hence the conclusions are only indicative. More such studies with greater reach and better study design are required for the better understanding regarding the topic, as well as better generalization of the result. Being a self-administered questionnaire, reporting bias cannot be totally eliminated; there may be overestimation of good attitude towards organ donation. Many confounding factors like various variables of family background, health status, IQ, personality etc., may affect the results but due to time and feasibility constraints these were not controlled. Confirmation or follow up was not sought for those who were interested in donating organs.

\section{CONFLICT OF INTEREST}

The authors declare no conflict of interest.

\section{REFERENCES}

1. World Health Organization. About WHO - What we do. Geneva: World Health Organization. 2019. Available from: https://www.who.int/about/what-we-do.

2. World Health Organization. Ethics, Access and Safety in Tissue and Organ Transplantation: Issues of Global Concern. Madrid, Spain: World Health Organization. 2003.

3. Brannstrom M, Johannesson L, Bokstrom H, et al. Live birth after uterus transplantation. Lancet. 2015;385(9968):607-16.

4. Directorate General of Health Services. National Organ Transplant Programme. New Delhi: Ministry of Health and Family Welfare, Government of India. 2016 [Available from: https://dghs.gov.in/content/1353_3_NationalOrganTransplantProgramme.aspx.

5. Global Observatory on Donation and Transplantation. Global Data. Madrid Spain: Global Observatory on Donation and Transplantation. 2018. Available from: http://www.transplant-observatory.org/download/2016-activity-data-report/

6. Shroff S, Navin S. Deceased donation rate in India doubles in the last two years Indian Transplant Newsletter. 2015;14(44):841. Available from: https://www itnnews.co.in/indian-transplant-newsletter/issue44/Editorial-desk-Deceaseddonation-rate-in-India-doubles-in-the-last-two-years-841.htm

7. National Health Portal. Organ donation day. New Delhi, India: Ministry of Health and Family Welfare, Govt. of India. 2016. [Accessed 12 June 2019]. Available from: https://www.nhp.gov.in/Organ-Donation-Day_pg

8. Panwar R, Pal S, Dash NR, Sahni P, Vij A, Misra MC. Why are we poor organ donors: A survey focusing on attitudes of the lay public from northern India. Clin Exp Hepatol. 2016;6(2):81-6. Available from: https://www.ncbi.nlm.nih.gov/ pmc/articles/PMC4963316/

9. Srivastava A, Mani A. Deceased organ donation and transplantation in India: Promises and challenges. Neurol India. 2018;66(2):316-22. Available from: http://www.neurologyindia.com/text.asp?2018/66/2/316/227259

10. Singh $P$, Kumar A, Sharma RK. Factors influencing refusal by relatives of braindead patients to give consent for organ donation: Experience at a transplant centre. J Indian Med Assoc. 2004:102(11):630, 632-43.

11. Sarveswaran G, Sakthivel MN, Krishnamoorthy Y, Arivarasan Y, Ramakrishnan J. Knowledge, attitude and practice regarding organ donation among adult population of urban Puducherry, South India. J Edu Health Promot. 2018:7:117. Available from: http://www.jehp.net/temp/JEduHealthPromot71117-2447505_064755. 
pdf

12. Bharambe VK, Arole VU, Puranam V, Kulkarni PP, Kulkarni PB. Knowledge and attitude toward organ donation among people in Lanja: A rural town in India. Saudi J Kidney Dis Transpl. 2018;29(1):160-6. Available from: http://www.sjkdt. org/text.asp?2018/29/1/160/225209

13. Bharambe VK, Rathod H, Paranjape VM, et al. Awareness regarding body and organ donation amongst the population of an urban city in India. Nitte Univ $J$ Health Sci. 2015;5(4):51-7. Available from: http://nitte.edu.in/journal/December\%202015/8.pdf

14. Balajee KL, Ramachandran N, Subitha L. Awareness and attitudes toward organ donation in rural Puducherry, India. Ann Med Health Sci Res. 2016;6(5):28690. Available from: https://www.amhsr.org/articles/awareness-and-attitudestoward-organ-donation-in-rural-puducherry-india.html

15. Tamuli RP, Sarmah S, Saikia B. Organ donation - "attitude and awareness among undergraduates and postgraduates of North-East India". J Family Med
Prim Care. 2019;8(1):130-6.

16. Shweta T. Tamil Nadu leads in organ transplants for fourth consecutive year. Deccan Chronicle Nation: Current Affairs. 2018. [cited on 2019 June 19] Available from: https://www.deccanchronicle.com/nation/current-affairs/281118/ tamil-nadu-leads-in-organ-transplants-for-fourth-consecutive-year.html

17. Vijayalakshmi P, Sunitha TS, Gandhi S, Thimmaiah R, Math SB. Knowledge, attitude and behaviour of the general population towards organ donation: An Indian perspective. Natl Med J India. 2016:29(5):257-61. [cited on 2019 June 19] Available from: http://www.nmji.in/temp/NatIMedJIndia295257-1148007_031120. pdf

18. Maroof S, Kiyani N, Zaman Z, Gul RK, Nayyar S, Azmat A, et al. Awareness about organ donation especially kidney donation in Nurpur Shahan, a rural community area in Islamabad, Pakistan. J Pak Med Assoc. 2011:61(8):828-32. [cited on 2019 June 19] Available from: https://jpma.org.pk/article-details/2944?article_ id $=2944$

Cite this article : Sunil DS, Baliram WV, Raghunath KP, Bhimrao DG. Awareness and Attitude towards Organ Donation: A Community Survey in Urban and Rural Populations, from Sangli District of Maharashtra. Int J Med Public Health. 2019;9(3):87-92. 